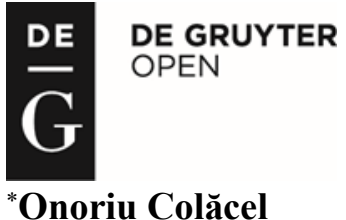

Faculty of Letters and Communication Sciences,

Ştefan cel Mare University of Suceava,

13 Universităţii Street, 720229 Suceava, Romania

e-mail: onoriucolacel@litere.usv.ro

*Corneliu Pintilescu

George Baritiu History Institute of the Romanian Academy, Cluj-Napoca

12-14 Mihail Kogălniceanu street, 400084 Cluj-Napoca, Romania

e-mail: pintilescu2001@yahoo.com

\title{
FROM LITERARY CULTURE TO POST-COMMUNIST MEDIA: ROMANIAN CONSPIRACISM
}

\begin{abstract}
Conspiracy thinking has a long history in Romanian literary culture. In the early $21^{\text {st }}$ century, what counts as a conspiracy theory in the mainstream of Romanian life is nevertheless elusive enough to keep the public engaged more than ever before. The growing number of attempts to address the gap in knowledge with regard to local conspiracy theories is proof that concern with their possibly harmful consequences is on the rise as well. For most of the conspiracy-minded, the topics of the day are specific threats posed to post-communist Romania and its people. In the main, conspiratorial beliefs fall into three main fields. Namely, they come across as 1) conspiracy theories against the body politic of the nation, 2) health-related conspiracy theories and 3) conspiracy theories on use and conservation of natural resources. While the first two overlap and build on the tradition of home-grown populism, the third is mostly a borrowing from Western media sources. However, the most influential instances of Romanian conspiracism posit that the well-being of the nation's body politic and that of individuals' own bodies are one and the same.
\end{abstract}

Keywords: conspiracy narratives, conspiracism, Romanian conspiracy theories, Romania

A breeding ground for conspiracy theories

Hidden in plain sight, conspiracy theories (CTs) have always been around in the mainstream of Romanian life. Ever since the principalities of Wallachia and Moldova united back in 1859, Romanian literature and history books have developed the master story of the nation into an all-consuming piece of drama with conspiracy overtones. A continuous feedback between politics and literary culture and, lately, between literary and popular cultures, has led to a steady growth of conspiracy thinking on Romania as a nation always fretting about its possible decline.

We read a narrative of historical turning points that are steeped in conspiratorial thought so that readers can understand the afterlife of Romanian CTs in post-communist media. Our approach stands

This work was supported by the COST Action: Comparative Analysis of Conspiracy Theories (COMPACT), CA COST Action CA15101 (2016-2020) funded by the European Union Framework Programme Horizon 2020.

* Onoriu Colăcel is Reader in English at Ștefan cel Mare University of Suceava, Romania. His main research interests are concerned with postcolonial studies, cultural memory and patterns of self-identification in literature, media and popular culture.

* Corneliu Pintilescu is Senior Researcher at George Barițiu History Institute of the Romanian Academy, ClujNapoca. His main research interests are history of communism, politics of memory in post-communist Romania, church and state relations in Eastern Europe. 
on a constructivist view of conspiracy ideation "conceptualized [...] as a general predisposition" (Grzesiak-Feldman, 2015: 114) among the Romanian writers and reading public. If one is to trust conspiracy-theory scholars, for example M. R. X. Dentith, now living in Romania ${ }^{1}$, the country is far from being a 'benign polity' as far as CTs are concerned. In fact, his stay in the country made him realize once again that "our notions of how conspired or unconspired our societies are $[\ldots]$ inform our judgements about how likely we think particular kinds of deceptive activities are" (Dentith, 2017).

A Romanian "superconspiracy [...] in which multiple conspiracies are believed to be linked together hierarchically" (Barkun, 2003: 6) gives a thorough account of the country's modern history. They all point to the making of the nation state and, later, to safeguarding its interests. Consequently, modern Romania appears to be the only possible outcome of a history made by "collective narcissists" (Cichocka et al, 2015: 42) who find comfort in belonging to their own "imagined community" (Anderson, 2006: 35). Yet, the long-standing assumption that irrationality accounts for CTs (Hofstadter, 1965; Popper, 1969) cannot possibly explain the teleological past that undergirds the present of Romanian CTs. As a flawed way of thinking such narratives would fail to account for the culture-bound meanings they seem to convey to most if not all ethnic Romanians, irrespective of their political stripe and educational background. The "Romanians have more than once felt betrayed" (Boia, 2001a: 175) by Western democracies and global organizations. The attribution of collective agency to historical neighbours as well as to some specific members of their own community (mostly, to ethnic minorities) means that local CTs are now woven deeply in Romanian culture, as much as, for example, the folklore of "vampire-like creatures [...] [that] impress through a sense of normality" (Balinisteanu, 2016: 169).

One way or another, conspiracism has become highly significant to $21^{\text {st }}$ century Romanians. Canonical literature, history textbooks and post-communist media have invested time and resources into appeals to the public to take a stand for their Romanianness. This does not mean that Romanian literary culture follows the lead of far-right ideologies in denouncing equality among ethnic groups on what would necessarily appear to be xenophobic nationalism (Mudde, 2007). On the contrary, both the literary and the popular cultures of Romania are rife with, for instance, speculation about the innate failure of the local society to respond to the challenges of EU membership. There is even condemnation and ridicule for Romanian laziness and criminality. Despite that, the conspiracy-minded wave the national flag as a warning sign. They fear the nation might descend into secession and, possibly dissolution, if the people do not come forward to state their case for an ethnocentric mind-set. Essentially, most Romanian conspiracy narratives posit that the well-being of the nation's body politic is hard to tell apart from that of individual citizens' bodies. To some extent, the local CTs form a

\begin{abstract}
a basis for constructing the NWO [New World Order] explanatory frame [...], which depicts the systemic eradication program of the white race, nation states, traditional family, etc. Those frames are noteworthy because of their ability to connect seemingly incompatible or even controversial discourses and signifiers into a single syncretic interpretation. (Madisson, 2016: 191)
\end{abstract}

Romanian CTs are "essentially social constructs" (Butter \& Knight, 2016: 10), later appropriated by various public narratives. Reports on political events place the people in contrast with a privileged elite, out-of-touch with ordinary Romanians. Consequently, local CTs have long gained momentum as populist discourses mobilised by mainstream media. Most of them are "conspiracy theories about conspiracy theorists" (Aupers, 2012: 23). This kind of storytelling, nevertheless, gives a coherent reading of the past and effectively shows the people's "exclusion from the political system" (Drochon \& Fredheim, 2015).

\title{
A Look at the Past: Conspiratorial Skills to Build the Nation
}

The elites of Romania have a long tradition of pursuing the establishment of a new social order, which was supposed to bring the country in line with either the West or the East. At one time or another, Europe, the USSR and, lately, the EU have provided the benchmark against which the nation would be judged by its own citizens. Throughout time, the country has always been a battleground for its

\footnotetext{
${ }^{1}$ At the time this article was published.
} 
historical neighbours and the East-West divide provides a compelling explanation for most momentous events of the past.

In hindsight, it is safe to say that the story of how the people who built the nation stood up to Eastern European Empires features the moneyed and educated classes of the Romanian principalities. For the most part, they were responsible for the production of literature as well as for those aspects of culture that are related to the consumption of fiction and history. According to history textbooks (Bozgan et al, 1999; Dumitrescu et al, 2002, Băluțiou \& Grecu, 2007), the Western-educated elites of the $19^{\text {th }}$-century Wallachia, Moldavia and Transylvania were embroiled in conspiracies first and foremost as ethnic Romanians. For all intents and purposes, they were struggling to wrench their lands from expansionist neighbours. No wonder, then, that it was their standing in Romanian society that fostered conspiratorial beliefs among everyone else.

As makers of a literary culture, national-minded Romanians have a long history of looking into the political realm only to find the invisible hand of the imperial neighbours that ruled over their lands. This is where local conspiracy thinking used to find its only expression and limits. The language recorded conspiracies mostly as seditious acts (i.e. 'hiclenie', 'hainie', 'hainlâc'2). They were subversive and political to their core: "The Russians, the Germans or the Ottoman Turks were always asked to take sides in local squabbles by the local elites (the boyars)"3 (Vintilă-Ghițulescu, 2013: 44). The establishment of the Romanian principalities, prior to the union of 1859, had to accommodate the foreign policy of neighbours due to poor military strength and leadership. Consequently, the wealthy members of the upper classes came to be seen as having their own interests at heart. As a matter of principle, they failed to win popular endorsement when in public office. In the words of one of them, they acted unpatriotically "knowing full well how defenceless the country was, no army, most of the boyars emasculated by more than a hundred years of Phanariot rule, the people having lost the military skills of their forefathers"4 (Rosetti, 2013: 82). However, they had what it took to "read French magazines that $[\ldots]$ were translated into thousands of new copies and made the apology of the ideas and revolutionary actions in France"5 (Sion, 2014: 153).

Widespread suspicion of foreign-appointed leaders runs deep into the history of the Romanian people. Later on, major events would confirm suspicions that the hidden agenda of historical neighbours is behind engagement with civic affairs. The idea of conspiracy has developed gradually, with a steady flow of French borrowings into Romanian ('intrigă', 'felonie', 'conspirație', 'conjurație', 'complot'6). As a principle, public opinion became increasingly aware of Western-developed ideas about CTs and secret societies. The establishment of the nation state from 1859 to 1866 is believed to be a consequence of young politicians' endeavours, mostly members of the landed elite and professional people who got involved in the European revolutions of 1848 and secret organizations. As a result, politically conservative milieus in the Romanian principalities accused young revolutionaries (i.e. Nicolae Bălcescu, Mihail Kogălniceanu, Al. I. Cuza, Ion C. Brătianu) of conspiracy against the old social order: in other words, of spreading the "dangerous ideas" of democracy and freedom of expression (Marcu, 1930: 18-23). Most of those who sought to bring their country in line with the standards of Western democracies graduated from French universities and developed a deep understanding of the ideals that underwrite the idealism of European revolutions. Consequently, the political terminology in Romania translation - including words dealing with the notion of CT - have a French origin. Even the word 'secret' was yet another French import that replaced less prestigious ones, of Latin origin (i.e. 'ascuns', 'ascunziș'), and older Slavonic borrowings into Romanian (i.e. taină).

The French-educated made sure that the Romanian "rhetoric of literary sociability was contradictory: 'a secret pact' lay behind [...] 'public works'; the aims were both to stay independent of politics and to determine a national regeneration". Factually, the local intelligentsia "was embroidering the idea of literature in a narrative of secrecy and empowerment" (Drace-Francis, 2006: 87-88). For

\footnotetext{
${ }^{2}$ All three words mean 'political treason'.

3 "Rușii, nemții sau turcii sunt folosiți de boieri fără întrerupere". All translations of texts in Romanian are ours.

4 “Țara fiind lipsită de orice apărare, fără oaste, cei ai mulți boieri afemeiați prin mai bine de un veac de regim fanariot, poporul făcut prin toate chipurile să piardă obiceiul armelor”.

5 "gazetele franceze [...] se traduceau și, prin mii de copii răspândite, se făcea propaganda ideilor şi faptelor revoluționare din Franța".

${ }^{6}$ The loanwords mean the same as the ones they have gradually replaced, i.e. political treason.
} 
example, the factual literary genres, such as memoirs and diaries, discuss at length the year 1848 (Sion, 2013: 145-337), a time of political upheaval, strife and plots. They paved the way for real and imagined conspiracies, which hatched in the new political culture of the Romanian Principality (1859-1881) and of the Old Kingdom of Romania (1881-1914).

Historically documented instances of regime change shaped public attitudes toward political conspiracies. A band of conspirators took responsibility for deposing the first Prince of Romania, Al. I. Cuza, from the throne in 1866. The first German-born King of the nation, Carol I (1866-1914), brought about change in Romanian politics and new meaning to the suspicion that foreign power groups seek to impose their agenda on the people of the land. Early in his reign, the Moldovan elites wrote that: "The Romanians' natural-born aversion to Germany was caused by passionate reports in the liberal newspapers, reports that decried attempts to Germanize the army, as a first step towards making the whole country German"7 (Rosetti, 2013: 489). However, whatever his faults were, they would be eventually forgotten in his achievements: the independence from the Ottoman Porte and international recognition for the kingdom of Romania secured him a place among the founding fathers of Romania.

At the time of Greater Romania (1918-1940), "the state [was] on the cultural offensive" (Livezeanu, 2000: 29-48), which meant that mainstream public narratives were rife with paranoid overtones leading to the rise of Romanian fascism. In the aftermath of World War I, this "cultural offensive" was meant to homogenize a country that doubled its territory by taking large areas that belonged to the Austro-Hungarian and Russian empires. The offensive targeted the significant communities of Hungarian, Jewish and German citizens living at the time in Romania. Consequently, the rhetoric of CTs was very much alive and growing. National minorities resorted to CTs in order to expose the politics of nationalism carried out by the Romanian elites, while the Hungarians and the Jews were permanent fixtures of real and perceived conspiracies against the nation state. Namely, the Hungarians were indicted with plotting against the state in order to regain Transylvania. As for the Jews, they were conspiring to impose their control on Romania through their position in the financial sector and their significant presence in the liberal professions (Nastasă 2011, 19-20; 26). The Jewish conspiracy surfaced in the 1930s, fuelled by the local fascist movement, i.e. the Legion of the Archangel Michael. In a less virulent form, the anti-Semitic rants were quite common in post-communism as well. Taking into account the dwindling numbers of the Jewish community in post-communist Romania, Michael Shafir labelled the post-communist surge in anti-Jewish feelings as "anti-Semitism without Jews" (Shafir, 1993).

The traumatic experience of the past was conducive to a popular culture of disbelief with regard to all official communications. This could very well be the legacy of Ceaușescu's national communism. Although presently CTs are pathologized in the mainstream of Romanian life, traditionally, the mistrust about political elites was perceived by many as a rational choice. If one is to trust the history of Romanian literature (Popa, 2001; Ştefănescu, 2005; Negrici, 2002-2003), the subversive bent of the country's late $20^{\text {th }}$-century novel genre, not to mention the literature published in samizdat, was a strategy of coping with the regime, and possibly, with its conspiratorial certainties. In the build-up to full-blown national communism under Nicolae Ceaușescu, and after his "dynastic communism" (Tismaneanu, 2004: 30) was finally in place, victimhood clichés riddled Romanian public narratives. The national communism of Romania had everything to do with "populist nationalism" (Blokker, 2005). The kind of delusional grandeur the Romanian citizen have come to expect from the Secretary General in the 1980s, (i.e. from Nicolae Ceaușescu) rounds up the picture of a literally "paranoid style" (Hofstadter, 1965: 4) in communist politics. This plays into the larger narrative of the communist bloc where "totalitarian language is to be perceived as a manifestation of power in a rhetorical form" (Ventsel, 2009: 10).

In addition, some writers, journalists and film directors packaged their own stories in such a way that they fostered highly specific visions of Romanian life. Both the cultural elites and the public shared in the well-kept secret of grassroots opposition to the Communist Party: the famed resistancethrough-art during times of economic trouble is much talked about but has failed to materialize in anything worth mentioning except for culture-bound jokes and references to Romanian history. If anything, it helped the public become more aware of the double-talk and the impotence of Romanian

\footnotetext{
7 “Antipatia din naștere a românului pentru neamț fu stârnită prin violente articole ale presei liberale care denunțau această tentativă de nemţire a armatei, presagiu al unei proiectate nemțiri a țării”.
} 
leadership at the time. Likewise, it served to highlight a lack of political agency deeply embedded in Romanian conspiratorial thinking.

Once the communist regime fell, the public had to come to terms with the past. A big chunk of the people remember that they had to build socialism only to face the need for "transitional justice" (Stan, 2013). While trying to make sense of such developments, they discovered "a world full of antiRomanian conspiracy theories" (Gallagher, 2005: 275). Moreover, the conservative elites in politics made sure that everyone else but the native Romanian people is depicted either as foreign agents or saboteurs of the effort to safeguard the nation's heritage. Defending the possibility of CTs comes with the territory of political participation: for example, George Soros was blamed by the head of the government party that he "wants to harm Romania" (digi24, 2017) back in July 2017.

\section{Conspiracy Theorizing for Profit: Conspiracies in Romanian Media with a Focus on George Soros}

The post-communist Eastern Europe experienced a revival of nationalism that took over the empty space left by the fall of the state propaganda system (Tismăneanu 1999, 246-256). This reemergence of populism in Eastern Europe had the side effect of mainstreaming CTs. However, there was no need to revive Romanian nationalism: the propaganda of Nicolae Ceaușescu's regime relied heavily on national myth making. In the process, it also instrumentalized CTs through various channels. One of them was the magazine Săptămâna, led by the so-called court writers of Ceaușescu, Eugen Barbu and Corneliu Vadim Tudor. The ready availability of paranoid communication, throughout the regime of Ceaușescu who feared "that citizens might criticize political leaders" (van Prooijen \& Krouwel, 2015: 81), explains the currency of CTs in post-communist Romania. For post-communist conspiracy theorists, conspiracism is a mode of existence (Voicu, 2000).

There is consensus that "mass media stoke the flames of conspiracy theorizing for fun and profit" (Uscinski \& Parent, 2014: 123). In 1990, Eugen Barbu and Corneliu Vadim Tudor set up the magazine România Mare [Greater Romania], which gave new life to local CTs, this time for their own political profit. Ever since the regime change in 1989, cliché arguments and little interest in exploring critical perspectives on the past and the present have been staples of Romanian media culture. A case in point is România Mare, one of the main vehicles for promoting populism, xenophobic ideas and conspiracy theories in post-communist Romania. Corneliu Vadim Tudor also founded a nationalist political party with the same name, which later succeeded in gaining a significant number of seats in the Romanian parliament from 1990 to 2008. România Mare was well known for promoting fears and nationalism at election times (Cinpoes, 2010: 149-166). As a result, the Jewish and the Western conspiracy to dismantle the Romanian state, the Hungarian conspiracy to take back Transylvania, or the European Union as a plot against nation states took to the fore. These and other narratives have a history in the CT of Judeo-Bolshevism, which argued that the Romanian Jews were guilty for the Stalinization of Romania, and the Judeo-Masonic CT, a global Jewish cabal that threatened to bring down the nation state of Romania. The Jewish-led conspiracy played well into the hands of Vadim Tudor who blamed the International Monetary Fund for everything wrong in post-communist Romania.

The anti-Semitic rhetoric of the magazine overlapped with the anti-Hungarian discourse. The case in point is the Soros conspiracy. After enjoying a period of popularity during the 1990s and the early 2000s, the magazine România Mare and the party with the same name fell out of favour with the public. Nevertheless, George Soros was here to stay: he is the embodiment of both Jewish and Hungarian CTs in Romanian far-right politics. What is more, most of the CTs once promoted by Vadim Tudor have spilled over into the mainstream press.

Nowadays, skepticism about state institutions and confidence in one's own ability to tell truth from fiction do not have much to do with education or political convictions. When it comes to CTs, there is no war of ideas. Most of the times, entertainment value takes precedence over factual references. For the most part, Romanian media shows that current conspiratorial beliefs fall into three main fields: 1) CTs against the body politic of the nation, 2) use and conservation of natural resources CTs and 3) health-related CTs. While the first two overlap and build on the tradition of home-grown national populism, the third is mostly a borrowing from Western media sources. The attempt to look at the past in order to rationalize failure to live up to the standards of the present is a common place in local conspiracism. The East-West divide, much like the clash of civilizations, is supposed to explain the very chaotic landscape of post-communist Romania. 
Currently, the most compelling strands in the narrative of Romanian conspiracist storytelling are:

- the Romanian revolution of 1989 as a coup d'état;

- vaccination scare stories;

- the EU as a sinister organization;

- the new German empire of Europe;

- Russian agents and conspirators;

- the brain drain as a conspiracy of the West;

- federalization as a threat to the future of the nation;

- genetically-modified (GM) foods;

- dwindling demographics conspiracies;

- IMF and the global finance conspiracy

- blueprints for dismembering the country: the Magyar conspiracy with a focus on Transylvania

- the Soros-backed NGOs conspiracy

Coming back to George Soros, he is the epitome of the Jewish financial CT in most Romanian conspiracy narratives. Due to his life history ${ }^{8}$, he was presented prior to the EU accession of the country as the mastermind of a plan to undermine the institutions of the new, democratic Romania. However, he was a marginal figure in Romanian politics, seldom mentioned in mainstream media.

The Soros conspiracy came back in the limelight from 2015 onwards, when the Romanian people took to the streets in protest at corruption. During the mass protests of November 2015, following the Colectiv club blaze that led to the death of 64 people, the pro-government media accused protesters that they were instigated and even paid by Soros-backed NGOs (Zachman \& Eremia, 2016). A similar scenario took place in January-February 2017, when the Romanian government sought to decriminalize offences related to corruption in public office. According to the same news outlets and media pundits, George Soros once again paid protesters to take down the newly elected administration (Mihăilescu, 2017).

This and other CTs found an audience among those sharing nationalist views, such as the former public of România Mare. On the one hand, this is the afterlife of the nationalist and xenophobic rhetoric of the 1990s and early 2000s. So, although deployed in a different context and developing a somewhat more assertive strategy, this time meant to ensure the survival of current political elites, the Soros conspiracy is familiar to a public already primed to distrust the West. On the other hand, there are arguments that render the scenario of a country under the siege of globalization plausible to those who feel left behind by the pace of change in post-communist Romania. There is no doubt that the Open Society Institute doled out grants to politically favoured groups, which in turn promoted democracy, liberalism and human rights (with a focus on national and religious minorities). Effectively, George Soros contributed in a decisive manner to the growth of today's civil society in Romania. Over the last two decades, those in power have been traditionally targeted by harsh criticism coming from a host of NGOs loosely connected to him. In the last three years, reports on Romanian intellectuals who formerly benefited from the so-called Soros fellowships and grants circulated in Romanian media (Şomănescu, 2015). Even a list of their names was invoked as a proof of how the Jews "bought" Romanian intellectuals (Ionescu, 2016). The conspiracy-minded asserted that behind his financial support lurk occult interests. As Matthew Dentith argued, there is no doubt that Soros-backed NGOs exposed and, to some extent, dislodged local networks of corruption (Ștefănuţ, 2017), which must be part of the reason why he is in the crosshairs of a number of influential politicians across Eastern Europe.

Conclusion

Romanian CTs are not one of a kind. Essentially, their rhetoric is no different from that of the better-known CTs of the Western world. For instance, Romanian conspiracism is very 'American', i.e.

\footnotetext{
${ }^{8}$ I have in mind his stock market gains, the democratization and human rights agenda that he laid out for Eastern Europe and his involvement with the Budapest-based Central European University, where many Romanians looked to continue their education in the aftermath of the regime change in 1989.
} 
"highly ambiguous, wavering between the literal and the metaphorical as it circles around the problems of agency, responsibility and blame" (Knight, 2000: 158). Except for historical circumstances associated with nation building, the local conspiratorial fears are "also motivated by the compelling narrative structures of most conspiracy theories themselves, particularly in their Manichean worldview" (Oliver \& Wood, 2014: 953).

As elsewhere across post-communist Europe, concerns about democratic accountability and the state of the economy are on most people's minds, which is fertile ground for conspiracy theorists. Much like in Bulgaria, "the narrative of corruption has become politically unquestionable" (Hristov, 2017: 8) and has all the trappings of a Romanian conspiracy. Moreover, the frame of reference employed by Romanian CTs is somewhat similar to that of Polish conspiracism: the Romanian reading of history is informed by "one's own victimhood" (Cichocka et al, 2015: 45) as well. In this discourse, the struggle of the people against historical neighbours and foreign settlers helps explain the master story of the nation. The newcomers on the land that would later become Romania are the Transylvanian Saxons, the Magyars of the same area (i.e. Transylvania), and the Russian-speaking population of Bessarabia (i.e. the present-day Republic of Moldova). Both settlers and natives come across as heroes of "airtight, all-encompassing systems of thought" (Bennett, 2007: 176), which, through the lens of conspiracism, deal with conflicting memories in a compelling manner.

Media coverage of George Soros is a case in point that Eastern European CTs have what it takes to go global. Although rooted in the politics of the 1990s, the latest developments of the Romanian conspiracy narrative that revolves around him are shaped by what happened from 2014 to 2017 across Eastern European countries ${ }^{9}$. The accusation that Soros paid the protests against Donald Trump, after he won the presidency of the US, only adds to this picture of the so-called bleak future of Eastern European nations in the age of globalisation. Possibly for the first time, a CT that originated in this part of the world became common knowledge in the West (Nazaryan, 2017). Even though shaped by local contexts, the legend of Soros in the local media is a good example of how conspiracism permeates political discourses on a global scale.

The story of us-versus-them underpins conspiratorial thinking in Romanian public narratives. However, what counts as a conspiracy in the mainstream of Romanian life is somewhat different from what CTs have to say about the modern nation of Romania. Most of them are value-laden narratives and normative forms of popular knowledge. As of the late 2000s, CTs in Romanian media move on from partial disclosure of historical facts and whispering in the corridors of power to speculating about the topical issues of the day. Social media and shorter news cycles are behind a new trend of conjectural reasoning in conspiratorial thinking. As everywhere else, the most effective CTs are the ones the public willingly participate in. The fact that CTs are highly publicized in social media and the complacency of the state's media watchdog help conspiracy theorists circumvent public accountability. It is likely that the Romanian public will see more and more media pieces that shift emphasis from CTs themselves to the knowledge they offer to audiences. Although the local CTs do not appear to strike a discordant note among the European ones, specific turning points in Romanian history have led to context-bound conspiracy narratives that can have implications for the civic health of the nation.

\section{Works Cited}

Anderson, B. 2006. Imagined Communities (revised edition), London and New York: Verso.

Aupers, S. 2012. "Trust no one': Modernization, paranoia and conspiracy culture", European Journal of Communication 27(1), pp. 22-34, DOI: 10.1177/0267323111433566.

Balinisteanu, T. 2016. "Romanian Folklore and Literary Representations of Vampires", Folklore, 127:2, pp. 150-172, DOI: 10.1080/0015587X.2016.1155358.

Barkun, M. 2003. A Culture of Conspiracy. Apocalyptic Visions in Contemporary America, Berkeley and Los Angeles: University of California Press.

Băluțiou, V. and Grecu, M. 2007. Istorie. Manual pentru clasa a XII-a [History. Twelfth Grade Textbook], Bucharest: Editura Didactică și Pedagogică.

Bennett, B. P. 2007. "Hermetic Histories: Divine Providence and Conspiracy Theory", Numen, 54 (2007), pp. 174-209, DOI: 10.1163/156852707X185005.

\footnotetext{
${ }^{9}$ In Hungary, Poland and the Russian Federation.
} 
Blokker, P. 2005. "Populist Nationalism, Anti-Europeanism, Postnationalism, and the East-West Distinction”, German Law Journal 6 (2), pp. 371-389.

Boia, L. 2001. History and Myth in Romanian Consciousness, Budapest and New York: Central European University Press.

Bozgan, Ovidiu, Lazăr Liviu, Stamatescu Mihai and Teodorescu Bogdan. 1999. Istorie. Manual pentru clasa a XII-a [History. Twelfth Grade Textbook], Bucharest: All Educational.

Butter M, Knight P. 2016. "Bridging the Great Divide: Conspiracy Theory Research for the 21st Century”, Diogenes, DOI: 10.1177/0392192116669289, pp. 1-13.

Cichocka A., Golec de Zavala A., Marchlewska M., Olechowski M. 2015. "Grandiose delusions: Collective Narcissism, secure in-group identification and belief in conspiracies", Bilewicz, M. Cichocka A., \& Soral, W. (eds.), The Psychology of Conspiracy, Oxon, UK: Routledge.

Cinpoes, R. 2010. Nationalism and Identity in Romania. A History of Extreme Politics from the Birth of the State to EU Accession, London : I.B. Tauris.

Dentith, M.R.X. 2017. "Conspiracy theories on the basis of the evidence", Synthese, https://doi.org/10.1007/s11229-017-1532-7.

digi24. 2017. "Dragnea: Totul pleacă de la Soros, de la răul pe care vrea să-l facă României" [Dragnea: Soros is behind everything, he wants to harm Romania], available at http://www.digi24.ro/stiri/actualitate/politica/dragnea-totul-pleaca-de-la-soros-de-la-raul-pecare-vrea-sa-1-faca-romaniei-757651, accessed on 8.09.2017.

Drace-Francis, A. 2006. The Making of Modern Romanian Culture. Literacy and the Development of National Identity, London, New York: Tauris Academic Studies.

Drochon, H., Fredheim, R. 2015. "Complete Losers: Conspiracy Ideation and Suspicion of Elites in Great Britain", available at http://www.conspiracyanddemocracy.org/blog/are-conspiracy-theories-for-complete-losers/, accessed on 19.01.2017.

Dumitrescu, N., Manea M., Niță C., Pascu A., Trandafir A. and Trandafir M. 2002. Istoria Românilor. Manual pentru clasa a XII-a [History. Twelfth Grade Textbook], fourth reprint, Bucharest: Humanitas Educational.

Ionescu, S. 2016. "Reţeaua Soros. Bani “albi" pentru politicienii şi ONG-urile care se implică în viaţa politică din România" [The Soros Network: Good money for the politicians and the NGOs that get involved in Romanian politics] Evenimentul Zilei, November 7, 2016, available at http://evz.ro/reteaua-soros-bani-pentru-organizatiile-civice-1.html, retrieved on September 12, 2017.

Gallagher, T. 2005. Modern Romania. The End of Communism, the Failure of Democratic Reform, and the Theft of a Nation, New York: New York University Press.

Grzesiak-Feldman, M. (2015). "Are the high authoritarians more prone to adopt conspiracy theories? The role of right-wing authoritarianism in conspiratorial thinking", Bilewicz, M. Cichocka A., \& Soral, W. (eds.), The Psychology of Conspiracy, Oxon, UK: Routledge.

Hofstadter, R. 1965. The Paranoid Style in American Politics and Other Essays, Cambridge, MA: Harvard University Press.

Hristov, T. 2017. "Capitalists, Spies and Aliens: Conspiracy Theories in Bulgaria", Messages, Sages and Ages, Vol. 4, No. 2, pp. 7-17, DOI: 10.1515/msas-2017-0005.

Knight, P. 2000. Conspiracy Culture. From Kennedy to The X Files, London: Routledge.

Livezeanu, I. 2000. Cultural Politics in Greater Romania: Regionalism, Nation-building and Ethnic Struggle, 1918-1930, Ithaca and London: Cornell University Press.

Madisson, M-L. 2016. "NWO Conspiracy Theory: A Key Frame in Online Communication of the Estonian Extreme Right", Lexia. Rivista di semiotica, 23-24 Complotto, ISBN 978-88-548xxxx-x, pp. 189-208, DOI 10.4399/97888548xxxxx11.

Marcu, A. 1930. Conspiratori şi conspiraţii în epoca renaşterii politice a României, [Conspirators and conspiracies at the time of the political re-birth of Romania], Bucureşti: Cartea Românească.

Mihăilescu, A. 2017. "Manipulări la RomâniaTV. Cum au reacționat internauții când au aflat că "s-a plătit 30 de lei pentru fiecare câine" prezent la protest" [Lying on TV: What the people online had to say about 'every dog that brought to protesters 30 lei'] România Liberă, January 23, 2017, available at http://romanialibera.ro/actualitate/eveniment/foto---video--manipulari-la- 
romania-tv--burtierele-au-transmis-ca-la-protestele-din-bucuresti-s-au-platit-30-de-lei-decaine--50-de-lei-de-copil-si-100-de-lei-de-adult-438914, retrieved on September 09, 2017.

Mudde, C. 2007. Populist radical right parties in Europe. Cambridge: Cambridge University Press.

Nastasă, L. 2011. „Antisemitismul universitar în România (1919-1939). Studiu introductiv”, [The Antisemitism of Romanian universities (1919-1939)], Lucian Nastasă (ed.), Antisemitismul universitar în România (1919-1939): Mărturii documentare, [The Anti-semitism of Romanian universities (1919-1939): Proofs and Documents], Cluj-Napoca: Institutul pentru Studierea Problemelor Minorităţilor Naţionale/Kriterion.

Nazaryan, A. 2017. "No, Trump Supporters, the San Francisco Chronicle Didn't Prove Your Point

About 'Paid' Protesters," Newsweek, May 8, 2017, available at http://www.newsweek.com/trump-paid-protesters-san-francisco-chronicle-alt-right-596511, retrieved on September 12, 2017.

Negrici, E. 2002-2003. Literatura română sub comunism, [The Romanian Literature at the Time of the Communist Regime] vol. I-II, București: Editura Fundației PRO.

Oliver, J. E., Wood, T. J. 2014. "Conspiracy Theories and the Paranoid Style(s) of Mass Opinion", American Journal of Political Science, Vol 58, No 4, October 2014, pp. 952-966, DOI: 10.1111/ajps.12084.

Popa, M. 2001. Istoria literaturii române de azi pe mâine: 1944-1989, [The History of Romanian Literature at the Mercy of Fortune: 1944-1989], vol. I-II, București: Semne.

Popper, K. R. 1969. The open society and its enemies (5th ed., Vol. 2), London, Henley: Routledge and Kegan Paul.

Rosetti, R. 2013. Amintiri, [Memories], București: Humanitas.

Shafir, M. 1993. "Anti-Semitism without Jews in Romania", Anti-Semitism in Post-Totalitarian Europe, Prague: Franz Kafka Publishers, pp. 204-226.

Sion, G. 2014. Suvenire Contimpurane, [Contemporary Memories], Iași: Polirom.

Stan, L. 2013. Transitional Justice in Post-Communist Romania. The Politics of Memory, New York: Cambridge University Press.

Șomănescu, M. 2015. "Lista lui Soros. Cine sunt oamenii care au schimbat România, cu sau fără voia noastră: miniștri, demnitari de rang înalt, jurnaliști” [The list of Soros. The people who changed Romania with or without our consent: ministers, top officials and journalists], Activenews, 18 may 2015, available at https://www.activenews.ro/stiri-politic/Lista-lui-Soros.-Cine-suntoamenii-care-au-schimbat-Romania-cu-sau-fara-voia-noastra-ministri-demnitari-de-ranginalt-jurnalisti-112622, retrieved on October 13, 2017.

Ştefănescu, A. 2005. Istoria literaturii române contemporane, [The History of the Contemporary Romanian Literature] Bucureşti: Editura Maşina de Scris.

Ștefănuţ, L. 2017. "Interviu cu cercetătorul Matthew Dentith" [Interview with Matthew Dentith] May 25, 2017, available at http://www.digi24.ro/opinii/cum-functioneaza-teoriile-conspiratiei-dinromania-pana-in-sua-interviu-cu-cercetatorul-matthew-dentith-731087, retrieved on September 12, 2017.

Tismăneanu, V. 1999. Reinventarea politicului: Europa Răsăriteană de la Stalin la Havel, [ReInventing Politics: Eastern Europe from Stalin to Havel], Iaşi: Polirom.

Tismaneanu, V. 2004. "Understanding National Stalinism: Legacies of Ceausescu's Socialism”, H., F., Carey (ed), Romania since 1989: politics, economics, and society, Lanham, Boulder, New York, Toronto, Oxford: Lexington Books, pp. 27-47.

Uscinski, J. E. and Parent, J. M. 2014. American Conspiracy Theories, New York: Oxford University Press.

Van Prooijen, J.-W., Krouwel, A. P. M. 2015. "Mutual suspicion at the political extremes: How ideology predicts conspiracy beliefs", Bilewicz, M. Cichocka A., \& Soral, W. (eds.), The Psychology of Conspiracy, Oxon, UK: Routledge: pp. 79-98.

Vintilă-Ghițulescu, C. 2013. Evgeniți, Ciocoi, Mojici. Despre obrazele primei modernități românesti, [Blue bloods, Upstarts, Commoners: The People of Early Modern Romania], București: Humanitas.

Ventsel, A. 2009. "The Role of Political Rhetoric in the Development of Soviet Totalitarian Language", 
Russian Journal of Communication, Vol. II, Nos. 1/2 (Winter/Spring 2009), pp. 9-25.

Voicu, G. 2000. Zeii cei rai. Cultura conspiratiei in Romania postcomunista, [The Evil Gods. Cospiracism in Post-Communist Romania] Iaşi: Polirom.

Zachman, S. and Eremia, R. 2016. "Delir: Soros a generat tragedia de la Colectiv, iar SRI şi DNA sunt versiunea 2.0 a Securităţii”, [Hallucination: Soros caused the Colectiv tragedy, SRI and DNA are the 2.0 iteration of the communist intelligence agency, 'Securitate'], December 9, 2016, Adevărul, available at http://adevarul.ro/news/politica/delir-soros-generat-tragedia-colectivsri-dna-suntversiunea-20-securitatii-1_584acaa05ab6550cb844bab7/index.html, retrieved on 14.08.2017. 